\title{
Employers' Perceptions of Employees with Mental Retardation in the Horticulture Industry
}

\author{
Mary E. DeHart-Bennett ${ }^{1}$ and Diane Relf ${ }^{2}$ \\ Department of Horticulture, Virginia Polytechnic Institute and State \\ University, Blacksburg, VA 24061
}

Abstract. The horticulture industry offers numerous unskilled and semi-skilled job opportunities for qualified disabled individuals. A survey of Virginia horticulture businesses was conducted to document the employment of persons with mental retardation and to investigate employers' perceptions of these workers. Employers' perceptions of the general work habits and entry-level horticultural skills of persons with mental retardation were favorable, and showed a potential for the development of positions that could be filled by people with mental retardation.

Rehabilitation facilities use horticulture as therapy and as vocational training for disabled persons. The American Horticultural Therapy Association operates three Projects With Industry programs designed to increase the participation of horticultural employers in the training and placement of disabled individuals within the horticulture industry. Despite these national efforts, documentation of their effectiveness is lacking.

Ornamental horticulture is labor-intensive and has a critical need for unskilled and semiskilled laborers in crop production and the service industries of interiorscaping, landscaping, and maintenance. However, a significant factor in the employment of persons with mental retardation is the employer's perception of the individual and the degree to which that individual can contribute to the business (Wolfe, 1980).

The goal of this study was to determine

Received for publication 17 Jan. 1989. The cost of publishing this paper was defrayed in part by the payment of page charges. Under postal regulations, this paper therefore must be hereby marked advertisement solely to indicate this fact. 'Graduate Student.

${ }^{2}$ Associate Professor. whether persons with mental retardation were perceived by employers as safe, dependable, and capable workers. Employers' opinions of the potential of persons with mental retardation, their general work habits, and specific horticultural job skills were gathered. The number of employers that have actually used this labor source was also determined.

A total of 557 surveys were sent out to a diverse selection of private horticultural firms in Virginia, including retail, wholesale, landscaping, and maintenance; 332 businesses responded. Thirty-three of the respondents were currently employing a person with mental retardation, and an additional 106 of the respondents had previously employed a person with mental retardation. The results are presented in two broad categories: 1) general work habits, and 2) horticultural skills.

General work habits. Employers' perceptions of the general work habits of persons with mental retardation are presented in $\mathrm{Ta}$ ble 1. For ease of interpretation, some of the responses have been pooled.

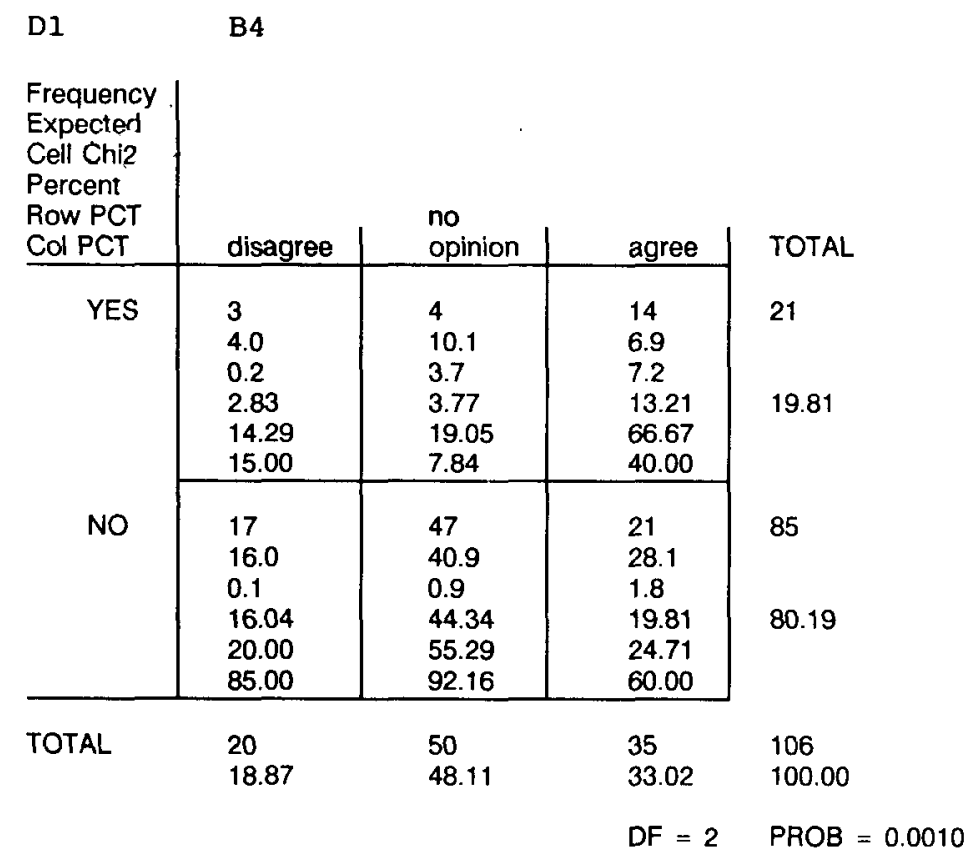

Fig. 1. Chi square-currently employing a person with mental retardation (D1) cross-classified with statement B4: insurance rates comparable to nondisabled employees. 
Table 1. Horticultural employers' responses to questions regarding the general work habits of employees with mental retardation.

\begin{tabular}{|c|c|c|c|c|}
\hline \multirow[b]{2}{*}{ Statements } & \multicolumn{4}{|c|}{ Response category $(\%)^{z}$} \\
\hline & Disagree & $\begin{array}{l}\text { No } \\
\text { opinion }\end{array}$ & Agree & $\begin{array}{l}\text { Unable to } \\
\text { judge }\end{array}$ \\
\hline \multicolumn{5}{|l|}{ Mentally handicapped workers: } \\
\hline 1. Want to work and like their jobs. & 2.5 & $8.1:$ & 58.5 & 31.3 \\
\hline 2. Get along well with supervisors. & 3.5 & 12.6 & 46.2 & 37.9 \\
\hline 3. Get along well with co-workers. & 5.5 & 14.4 & 40.4 & 40.1 \\
\hline $\begin{array}{l}\text { 4. Have insurance rates comparable } \\
\text { to nonhandicapped workers. }\end{array}$ & 7.0 & 17.4 & 11.1 & 64.5 \\
\hline $\begin{array}{l}\text { 5. Have safety records comparable } \\
\text { to nonhandicapped workers. }\end{array}$ & 8.7 & 13.8 & 22.7 & 54.8 \\
\hline $\begin{array}{l}\text { 6. Have attendance records comparable } \\
\text { to nonhandicapped workers. }\end{array}$ & 5.7 & 7.2 & 43.2 & 43.9 \\
\hline 7. Arrive and leave work on time. & 3.9 & 9.9 & 44.4 & 41.8 \\
\hline $\begin{array}{l}\text { 8. Are successfully employed in the } \\
\text { competitive labor market. }\end{array}$ & 9.9 & 11.9 & 33.1 & 45.5 \\
\hline $\begin{array}{l}\text { 9. Can perform many jobs as well } \\
\text { as nonhandicapped workers. }\end{array}$ & 9.0 & 5.7 & 51.3 & 34.0 \\
\hline
\end{tabular}

${ }^{2}$ Some row totals exceed $100-$ the actual figures were rounded to one decimal place for ease of presentation.

Table 2. Horticultural employers' responses to questions regarding the horticultural skills of employees with mental retardation.

\begin{tabular}{lcccc}
\hline \hline & \multicolumn{4}{c}{ Response category (\%) } \\
\cline { 2 - 5 } Tasks & Disagree & $\begin{array}{c}\text { No } \\
\text { opinion }\end{array}$ & Agree & $\begin{array}{c}\text { Unable to } \\
\text { judgc }\end{array}$ \\
\hline With appropriate training and a & & & & \\
moderate amount of supervision, & & & & \\
mentally handicapped workers can & & & & \\
successfully perform the following: & 2.4 & 3.9 & 64.4 & 29.3 \\
1. Use hand tools & 3.0 & 3.6 & 64.4 & 29.0 \\
2. Dig and shovel & 6.3 & 3.6 & 60.4 & 29.8 \\
3. Water plants & 5.7 & 6.0 & 56.6 & 31.7 \\
4. Load and unload trucks & 3.0 & 5.4 & 60.2 & 31.4 \\
5. Move plants with wheelbarrow & 11.4 & 9.9 & 45.2 & 33.5 \\
6. Plant seeds, cuttings, bulbs & 13.8 & 9.9 & 42.0 & 34.3 \\
7. Transplant annuals, trees, shrubs & 17.0 & 12.0 & 37.6 & 33.4 \\
8. Use pruners, clippers & 27.1 & 7.5 & 32.0 & 33.4 \\
9. Apply or assist fertilization & 38.8 & 7.5 & 19.3 & 34.4 \\
10. Apply or assist with pesticide & 25.0 & 7.0 & 35.6 & 32.7 \\
11. Operate lawnmower or weed-eater & 6.0 & 7.8 & 53.6 & 32.6 \\
12. Assist cleaning of equipment & 4.8 & 11.1 & 50.0 & 34.1 \\
13. Assist cutting and harvesting of & & & \\
flowers, fruit, and vegetables & 5.7 & 6.3 & 55.5 & 32.5 \\
14. Seed, thin, and cultivate & 3.3 & 4.8 & 62.0 & 29.9 \\
15. Clean work areas and buildings & & & & \\
\hline
\end{tabular}

${ }^{2}$ Some row totals exceed 100 - the actual figures were rounded to one decimal place for ease of presentation.

Regarding motivation and compatibility, nearly half of the employers surveyed gave responses indicating that they perceived persons with mental retardation as motivated, safe, dependable, and capable employees. Very few employers showed negative perceptions, indicating that, in general, horticultural employers have a positive perception of persons with mental retardation in the workplace.

Other studies have demonstrated the motivation and compatibility of persons with mental retardation (DuPont, 1982; Hill and Wehman, 1979; Hoskin, 1977; NARC, 1982; PCEH, 1982; Vandergoot and Worrall, 1979). These individuals have positive attitudes toward work, are proud of their jobs, and have effective relations with their co-workers and supervisors (NARC, 1982; PCEH, 1982).

Regarding insurance and safety, only a small percentage of the horticultural em-
Worrall, 1979; Wolfe, 1980). The DuPont company (1982) reported that $90 \%$ of 146 mentally disabled employees had average and above-average safety records. However, insurance and safety are major concerns of employers who are considering hiring a disabled employee for the first time (Jamero, 1979; Vandergoot and Worrall, 1979).

In regard to attendance and punctuality, perceptions of employers in Virginia's ornamental horticulture industry were favorable on this issue, with $>40 \%$ of the employers agreeing that employees with mental retardation have attendance rates and punctuality similar to nondisabled employees.

Studies on attendance and punctuality records of employees with mental retardation have also been favorable from food service, hotel/motel, and other industries (Hill and Wehman, 1979; Hoskin, 1977; PCEH, 1982; Vandergoot and Worrall, 1979).

Finally, regarding job performance, more than half of the horticultural respondents agreed that persons with mental retardation can perform many jobs as well as nondisabled workers. Again, there was a large percentage of respondents with no opinion, indicating a lack of awareness rather than a negative perception of the physical and mental abilities of persons with mental retardation.

Employees with mental retardation have been shown to be capable of good performance in a wide range of jobs in both sheltered and competitive employment situations (DuPont, 1982; NARC, 1982; Phelps, 1965).

Horticultural skills. Employers' perceptions of horticultural skills (Table 2) were based on 15 horticultural tasks divided into three areas of increasing skill and ability:

Minimum-skill activities necessary for entry-level positions in horticultural occupations require the ability to use common garden tools, minimal manual dexterity, and the ability to consistently repeat a sequence of tasks (tasks 1, 2, 3, 4, 5, 15). A very small percentage of the respondents disagreed that persons with mental retardation had these skills, indicating that the horticulture industry may be receptive to hiring these persons in entry-level positions.

Skill and judgment activities involve planting/transplanting and the use of nonpower cutting tools. They require manual dexterity, hand/eye coordination, and the ability to make judgments, such as determining planting depth or the ripeness of fruit (tasks 6,7, 8, 12, 13, 14). The greater disagreement with statements that persons with mental retardation hold skills at this level may be because many of these skills require considerable training even for nondisabled employees. However, persons with mental retardation are performing skill and judgment tasks in rehabilitation training centers, sheltered workshops, and competitive employment (Morris, 1978; Wolfe, 1980).

Complex and hazardous skill activities require more judgment to execute and involve risk factors such as the application of fertilizers and pesticides or the use of power equipment (tasks 9, 10, 11). Employers' 

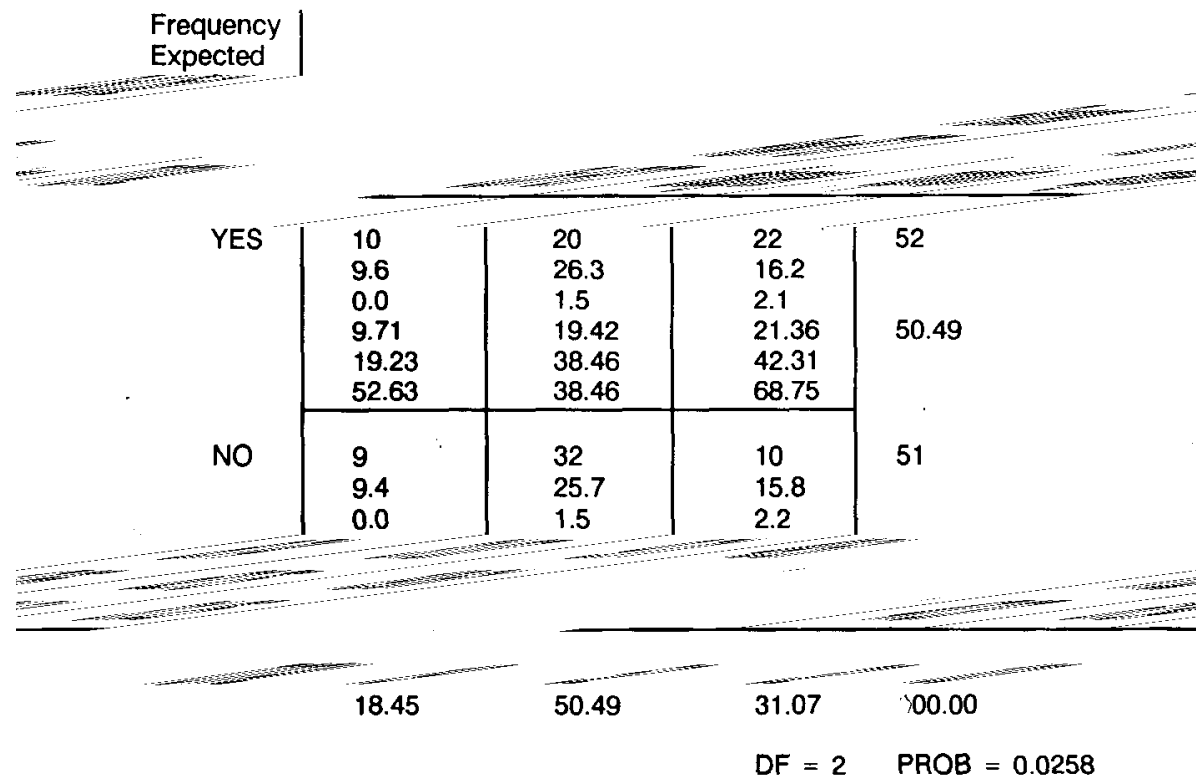

Fig. 2. Chi square-previous employment of persons with mental retardation (D2) cross-classified with statement B4: insurance rates comparable to nondisabled employees.

negative responses in this skill area and their concern regarding the insurance rates and safety records (Table 1) may have been in response to complex skills that are often required in horticultural businesses. Perceptions regarding insurance rates, safety, and the use of power equipment and garden chemicals were more favorable from employers with hiring experience.

The findings of this study have important implications in terms of the vocational training and employment of persons with mental retardation in the horticulture industry. Rehabilitation personnel are becoming more aware of the skills and traits necessary for employment in the horticulture industry and are working toward training their clients to suit the needs of the industry. Rehabilitation job placement specialists are being urged to contact horticultural employers to establish a communication network for updating employers' information on this resource and for placing persons with mental retardation in the industry.

The results of this study indicate that the horticulture industry may be willing to hire more people with mental retardation, but the major stumbling block is a lack of knowledge regarding the abilities of these people. It was demonstrated that those horticultural employers who had actually hired and worked with persons with mental retardation had more positive perceptions of their safety records and insurance rates than the others. Also, agreement with statements about work habits and horticultural skills was $10 \%$ to $30 \%$ higher among employers who had hired persons with mental retardation than among those who had not. When more horticultural employers become aware that persons with mental retardation are safe, dependable, and capable workers, the industry may have a labor resource it now lacks.

\section{Literature Cited}

DuPont de Nemours \& Co. 1982. Equal to the task: DuPont's survey of employment of the handicapped. E.I. DuPont de Nemours \& Co., Wilmington, Del.

Hill, M. and P. Wehman. 1979. Employer and nonhandicapped co-worker perceptions of moderately and severely retarded workers. J. of Contemp. Bus. 8(4):107-112.

Hoskin, N.A. 1977. Survey: employer viewpoints on hiring the mentally impaired. J. Spec. Ed. of the Mentally Retarded 14(1):3-6.

Jamero, P.M. 1979. Handicapped individuals in the changing work-place. J. of Contemp. Bus. $8(4): 33-42$.

Morris J. 1978. A vocationally oriented horticulture skill training program for the mentally retarded adult using task analysis. 6th Annual NCTRH Conf. 17-20 Sept. Topeka, Kan.

National Association for Retarded Citizens. 1982. We're not looking for a "handout." On-the-Job Training Project, Assn. for Retarded Citizens of the U.S., Arlington, Texas.

Phelps, W.R. 1965. Attitudes related to the employment of the mentally retarded. Amer. J. of Mental Defic. 69:575-585.

President's Committee on Employment of the Handicapped. 1982. Special report: disability and employment. Doc. 0-364-295. U.S. GPO, Washington, D.C.

Vandergoot, D. and J. Worrall (eds.). 1979. Placement in rehabilitation: a career development perspective. University Park Press, Baltimore, Md.

Wolfe, J. 1980. How the disabled fare in the labor market. Monthly Labor Review 103(9):48. 